\title{
La sátira y la invectiva en el diwan de R. Šelomó bar Reubén Bonafed
}

\author{
Arturo Prats Oliván* \\ Instituto de Filología - CSIC, Madrid
}

Bonafed es conocido por ser uno de los últimos poetas hispanohebreos ${ }^{1}$, junto a Šelomó bar Mešulam de Piera o Vidal Benvenist ben Labí, entre otros. Pertenecen, por tanto, al último periodo de desarrollo de la tradición literaria hebrea en la Península, periodo que siempre ha sido calificado por los estudiosos de la literatura como decadente, pues se considera que sus obras muestran una calidad inferior a las producidas en la Edad de Oro.

Mi aproximación al estudio de esta obra pretende reivindicar este periodo de la literatura hebrea tan denostado y plantear un acercamiento a la misma teniendo en cuenta sus peculiaridades y diferencias con respecto a la época clásica. Se trata, evidentemente, de la misma literatura hebrea que emana de una tradición anterior fuertemente enraizada en la cultura judía de la Península y con un amplio imaginario literario propio, pero que ya no se halla en el mismo contexto cultural que la vio nacer. Los escritores hebreos de la España cristiana vivieron y desarrollaron su obra en un contexto cultural completamente distinto, en el que la cultura dominante no era ya la árabe andalusí, sino la romance, como en la época de Bonafed. Como veremos, él se distancia en el tono y en algunas imágenes y recursos estilísticos de lo que había sido la tradición de la sátira hebrea

* pratsarturo@yahoo.com

1 Sobre la figura de Bonafed, véase A. M. a Bejarano, «Šelomo ben Reuben Bonafed poeta y polemista», Anuari de Filologia 14. Secc. E (1991), págs. 87-101; ID., «Šelomoh ben Reuben Bonafed, testigo del declive del judaísmo español en la Cataluña del siglo XV», en Proyección histórica de España III (Valladolid 1993), págs. 33-38; H. SchIRManN y E. Fleischer, The History of Hebrew Poetry in Christian Spain and Southern France (en hebreo) (Jerusalén 1997), págs. 626-655; H. Schirmann, Ha-širá ha- ivrit bi-Sfarad u-ve-Provans, 2 vol. (2a ed. Tel-Aviv 1960), págs. 620-623. 
clásica en la Península, aunque es indudable que es heredero de esta tradición literaria.

Para comprender mejor la literatura hebrea de esta época (ss. XIII-XV), debemos tener en cuenta la literatura romance. Probablemente algunos de los cambios que se han producido en la forma de escribir de Bonafed y de los escritores de su época guarde relación con la literatura provenzal, galaico portuguesa, castellana o catalana de la época, y no sólo con una evolución propia de la tradición hebrea.

El propósito de este artículo consiste en establecer estas posibles similitudes entre ambas literaturas, tomando como base los textos de estilo satírico y de invectiva del diwan de Bonafed ${ }^{2}$. Se trata de un diwan que todavía no ha sido editado ${ }^{3}$ en su totalidad, exceptuando, entre otros, los textos que componen la polémica con los dirigentes de la aljama de Zaragoza publicada por Schirmann ${ }^{4}$.

2 Estos textos se incluyen en la tesis doctoral que presenté el pasado año en la Universidad Complutense de Madrid, consistente en la edición crítica y traducción de los textos en prosa que conforman el diwan de Bonafed, La prosa en el diwan de R. Šelomo bar Re'uben Bonafed (s. XIV-XV).

3 Ediciones parciales de los poemas y escritos que aparecen en el diwan: H. Brody y M. Wiener, Mivḥar ha-širá ha- 'ivrit (2 ${ }^{\mathrm{a}}$ ed. Leipzig 1923), págs. 329-332; Schirmann, Ha-širá..., vol. 1; «Ha-pulmus šel Šelomó Bonafed be-nijbadé Saragosa», Kobetz al Yad, Tom. IV (XIV) (1946), págs 11-64; A. KaminKA, «Ha-diwan le-rabí Šelomó Bonafed», Mi-mizraḥ u-me-ma'arav 2 (1926-1928), págs. 107-127; ID., «Širim u-meliṣot le-rabí Šelomó ben Re’ubén Bonafed», Ha-ṣofé le-ḥojmat Yisrael 10 (1926), págs. 288-295; ID., Cobeș ma'amarim be-ḥojmat Yisrael (1928), págs. 33-42; Y. PATAI, «Širé ḥěšeq šel Šelomó Bonafed», Ha-ṣofé le-ḥojmat Yisrael 10 (1926), págs 220-223; ID., «Širé hol šel Šelomó Bonafed», Mașpuné ha-širá (Jerusalem 1939), págs. 67-85; A. M. ${ }^{a}$ Bejarano, Šelomo Bonafed, poeta y polemista hebreo (s. XIV-XV) (Tesis doctoral, Universidad de Barcelona 1989); A. SÁEnz-Badillos y J. Targarona, «Strophic Poems in the Dīwān of Šĕlomoh Bonafed», en Studies in Hebrew Literature from the Middle Ages and Renaissance. Homage to Yonah David [= Te'uda 19] (Tel Aviv 2003), págs. 21-46; A. Gross, «The Poet Solomon Bonafed and the Events of his Generation» (en hebreo), en The Frank Talmage Memorial Volume, ed. B. WALfish, vol. 1 (Haifa 1993), págs. 3561; T. VARDI, «A Wedding in Agramunt: The Wedding Poems of Solomon Bonafed» (en hebreo), Jerusalem Studies in Jewish Thought 14 (1993) págs. 169-196.

4 Schirmann, «Ha-pulmus», págs 11-64, comentados en E. GutwiRTH, «Contempt for the Lower Orders in XVth Century Hispano Jewish Thought» MEAH 30 (1981), págs. 83-98; ID., «Social Criticism in Bonafed's Invective and its Historical Background», Sefarad 45 (1985), págs. 23-53; ID., «The World Upside Down in Hebrew», Orientalia Suecana 30 (1981), págs. 141-147; ID., «Leer a Bonafed en su entorno», en La sociedad Medieval a través de la Literatura 
En primer lugar, compararemos los textos de Bonafed con la tradición andalusí y seguidamente con la literatura romance.

\section{LA INVECTIVA Y LA SÁTIRA EN LA TRADICIÓN LITERARIA HEBREA ANDALUSÍ}

Para describir cómo se concebía este estilo literario satírico en Al-Ándalus analizaremos primero lo que se dice de la sátira en la regla poética por excelencia de la literatura andalusí: el Kitāb al muḥādara wa-'l-mudhākara de Mošé ibn 'Ezrá, y exploraremos los escritos de los poetas clásicos de la edad de oro (Šemuel ha-Naguid, Šelomó ibn Gabirol, Mošé ibn 'Ezrá).

Pagis llevó a cabo un estudio sobre la poética de Ibn 'Ezrá y su obra ${ }^{5}$ en el que habla de la relativa «flexibilidad» de este género, heredado de la poesía árabe. En él se pueden conjugar, dentro de los poemas de «queja» (שירי תלונה), varios tipos:

La queja contra un amigo o عتاب (reprimenda o reproche), la queja en forma de monólogo شظظّ (quejarse de una injusticia) o شكوى (queja, aflicción), la sátira y crítica o هجاء y el auto-elogio o فخر

En el Kitāb al muhādara wa-'l-mudhākara, Mošé ibn 'Ezrá habla así de este género:

Por lo que respecta a la poesía satírica (الهجاء), jamás mi lengua pronunció una contra persona conocida, aunque el hablar de tal modo hubiera sido muy factible, Ya que destruir es más fácil que construir. Rara vez he sido puesto a prueba, gracias a Dios, por nadie, ni nadie ha sido probado por mí ${ }^{7}$.

\footnotetext{
Hispano-judía, eds. R. IzQuierdo y A. SÁenz-Badiloos (Cuenca 1998), págs. 341-357. Estos textos no se han conservado en el Ms. Oxford, Bodl. Mich 155 (1984). Las cartas que componen este ciclo contra los dirigentes de la aljama de Zaragoza, con los que Bonafed se enfrentó al final de su vida (1445-1450), son los textos compuestos en Belchite, localidad en la que se estableció tras haber sido expulsado de la aljama. En ellos vierte toda su cólera contra aquellos que le han humillado y, especialmente, contra R. Yosef ben Yešu'á, un rabino siciliano que es ahora uno de los dirigentes de la aljama y uno de los mayores responsables, aunque no el único, según Bonafed, de la corrupción y la maldad que imperan en Zaragoza, así como de su forzado exilio.

5 D. PAGIS, Širat ha-ḥol ve-torat ha-širá le-Mošé ibn 'Ezrá u-bené doró (Jerusalem 1970).

6 PAGIS, Širat ha-ḥol, pág. 282.

7 M. Ibn Ezra, Kitab al-muhadara wa-l-mudakara. Ed. y traducción de M. Abumalham Mas (Madrid 1985), pág. 57r/v; cf. PAGIs, Širat ha-ḥol, pág. 284.
} 
Y más adelante afirma:

Por necios semejantes no iba yo a poner mi alma a trabajar en nombrarlos ni manchar mis escritos en mencionarlos, sino que liberé a mis palabras de citarlos, apartando mis versos de hacerles reproches, porque para ellos hubiera sido un negocio lucrativo, un beneficio... Y en cuanto a aquéllos que, a mi entender, se podrían corregir con una reprimenda (بالعتاب) y no merecían permanente amonestación, la reprensión (العتاب) es lo que pule la amistad; uno tiene entre los amigos hermanos excelentes y débiles mentales. Quien reprende a los inmorales es como el que ofrece viandas a los habitantes de los sepulcros ${ }^{8}$.

En este mismo fragmento de la obra también dice:

En cuanto a la poesía de diatribas (المهاترة) y a la burlesca (المزاحمة), ambas fuera de lo poco que es digno de ser considerado bueno y dentro de lo mucho que se ha de considerar deplorable, poco las ejercí y no me complazco en recordarlas. A menos que se las considere como un error de juventud; como la poesía amorosa, algunas poesías festivas y muwaššahāt ${ }^{9}$.

Basándonos en estas afirmaciones podemos concluir que Mošé ibn 'Ezrá distingue en su poética entre la hijā', la sátira en la que se critica a un pueblo inculto o a grupos sociales concretos, gente con la que no tiene ninguna esperanza de acuerdo o reconciliación, y el 'atāb, la reprimenda o reproche, donde sí se menciona al sujeto, pero mantiene con él su amistad dejando una puerta abierta a la reconciliación.

También en los textos de Bonafed se da esta separación entre la crítica satírica y la invectiva. La primera se dirige contra un grupo social determinado, en la que puede atacar con toda su ira, pero de forma anónima, comportamientos impíos o corruptos como la ignorancia ${ }^{10}$. En la segunda

8 IBn Ezra, Kitab, pág. 59v; cf. PAGIs, Širat ha-ḥol, pág. 284.

9 Ibn Ezra, Kitab, pág. 57r; cf. A. Sáenz-Badillos, «Hebrew Invective Poetry: The Debate between Todros Abulafia and Pinhas Halevi», Prooftexts 16 (1996), 49-71, pág. 63.

${ }^{10}$ Carta 43, המים טובים, f. 105v-106r. Esta es la numeración que asigné en mi Tesis Doctoral a las distintas cartas del Diwan. En adelante citaremos los textos del Diwan señalando: a) el número de carta o poema asignado en la Tesis Doctoral, que responde al orden secuencial en el que aparecen los textos en el manuscrito Mich. 155 (1984) de la 
se dirige a un personaje concreto con la intención de llamarle la atención sobre algún tema en el que no estén de acuerdo pero dejando todavía un resquicio para la reconciliación ${ }^{11}$, como en las cartas que dirige a Šealtiel Bonafós ${ }^{12}$ en las que le reprende por no haber apreciado los poemas epitalámicos que envió para la boda de su hija y con el que se reconciliará posteriormente (cartas 23-25 ${ }^{13}$ ). Es notable también el hecho de que en algunas de sus cartas burlescas en contra de algún individuo en particular, como dirigida a un joven poeta de Híjar ${ }^{14}$, o la otra contra un muchacho estudiante de lógica ${ }^{15}$, Bonafed no menciona sus nombres. Sin embargo, sí deja un resquicio, aunque mínimo, para la reconciliación en la fórmula de despedida.

biblioteca Bodleian, Oxford; b) las palabras iniciales del texto o del poema correspondiente; c) el $n^{\circ}$ del folio en el ms. citado. En el caso de las cartas de la polémica con la aljama de Zaragoza, ya editadas en SchirmanN, «Ha-pulmus», págs 11-64; las citaremos según el número con el que se presentan en dicha edición, por ej. Schirmann 1.

11 Sobre esta distinción ver SáEnz-BAdILlos, «Hebrew invective Poetry», pág. 60; J. Middleton Murry, El estilo literario (México 1966), págs. 65-66; J. Rodríguez PuÉrtolas, Poesía crítica y satírica del s. xv (Madrid 1981), pág. 8; K. Scholberg, Sátira e invectiva en la España Medieval (Madrid 1971), pág. 11.

12 Bonafed compone unos poemas epitalámicos en honor de la boda de la boda de la hija de Šealtiel Bonafós y llega a sus oídos que no gustaron. Bonafed se ofende y escribe una serie de cartas hasta que finalmente, el padre de la novia se disculpa. Estos textos fueron estudiados en VARDI, «A Wedding in Agramunt», págs. 169-196.

13 Carta 23, Poema 111:עלו לי מקצה, f. 58v- 60r, texto 112: עפעפי יבחנו, 60r-61v; Carta 24, Poema 113: אל תשאלו, f. 61v-62v, texto 114: כי שמעתי אומרים, fr, f. 62v-63r; Carta 25, Poema 115:תשכת ימיני : למרעיש ממלכות, f. 63r-64r, texto 64r-64v.

${ }^{14}$ Las Cartas que componen este ciclo son seis. De las dos primeras sólo se han conservado los poemas que en ellas estaban incluidos: el Poema 133 (עד אן ידיד, f . 75r/v), compuesto por Bonafed, en el que se burla de un joven poeta; y el Poema 134 (שכל בהפרידו, f. 75v-76r), en el que Bonafed alude a la respuesta de este joven, la cual no se ha conservado. Tenemos también la Carta 35 (Poema 135, מה בחלום הזה, f. 76r/v; Texto 136, מה החלום הזה, f. 76v-77r; Poema 137, אל תתמהו, f. 77r), de Bonafed, y la Carta 36, en la que el mismo Bonafed alude nuevamente a una respuesta del muchacho que no se ha conservado, y que incluye un gran número de poemas sobre el tema (Poema 138, אם אחריש, f. 77v; Poema 139, אשאלך איזה, f. 77v; Poema 140, נפשי לאט, f. 77v-78r; Poema

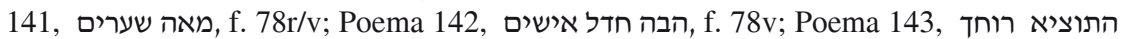
f. 78v; Texto 144, הארז אשר בלבנון, f. 78v-79r). Así pues, desgraciadamente, en este ciclo sólo se han conservado las réplicas de Bonafed, aunque gracias a los encabezamientos conocemos el contenido de las respuestas del muchacho.

15 Sobre esta carta véase A. SÁenz-Badillos y A. Prats, «Šelomo Bonafed y la lógica cristiana del siglo XV», Revista Española de Filosofía Medieval 10 (2003), págs. 15-27. 
Como vemos en los fragmentos aquí citados de su Kitāb al muhādara wa'l-mudhākara, Mošé ibn 'Ezrá, al igual que los poetas árabes occidentales ${ }^{16}$, no siente una especial simpatía por el género de la invectiva contra los enemigos, acto que considera igual al de «ofrecer viandas a los muertos».

Contrariamente a esta postura parece que la opinión que le merece a Bonafed este estilo literario de la invectiva no es negativa. De hecho, recomienda a uno de los destinatarios de sus cartas, Bonaguda Yahse'el ha-Cašlarí ${ }^{17}$, que no se deje llevar por la cólera ante los ataques de sus enemigos, y le dice así:

Refúgiate en tu fortaleza, como un héroe en su poder, y coge tu aljaba y tu tintero; desde allí, desde tus labios, se dispararán las flechas de reprobación contra el corazón de quienes te enojan ${ }^{18}$.

En otra carta explica que este estilo no está destinado sólo a herir al contrincante, sino que, en ocasiones, se siembra la discordia como un mero ejercicio literario para incitar a otros a escribir:

Así, mil veces saldrán antorchas de fuego de la boca de hombres de dichos puros y de excelsa prosa ya que éste es su deber, sembrar la discordia por medio de las poesías para despertar a los dormidos con palabras agradables, mitad cargadas de paz y verdad y mitad esgrimiendo lanzas ${ }^{19}$.

Aunque Mošé ibn 'Ezrá se pronuncia en contra del estilo satírico y burlesco, él mismo compuso sátira, a veces encarnizada, contra los ma-

${ }^{16}$ SÁenZ-BAdillos, «Hebrew invective Poetry», pág 61.

17 Tradicionalmente ha sido identificado con En-Bonaguda Halwa, pero es muy difícil saber cuándo se trata de él en los textos, ya que su padre tenía un nombre muy parecido, como podemos leer en el encabezamiento del poema לך דודי לך, Fol. 38-38v: «Unos versos que me compuso el sabio En-Bongu a Yaḥse el y su hijo querido Yaḥse el». Esta pequeña diferencia en la escritura del nombre no sirve para distinguir a ambos. Poseemos pocos datos biográficos sobre este personaje y su padre. Sabemos, a través de los textos, que se trata de una familia distinguida y que, como tal, acudió a la famosa boda de Agramunt (VARDI, «A Wedding in Agramunt») junto a otros invitados ilustres. Estamos hablando además, en ambos casos, de un sabio y un poeta, pues como tales son caracterizados, tanto el padre como el hijo, en muchos de los poemas que en su honor compone Bonafed. En no pocas ocasiones nuestro autor se declara fiel y humilde servidor de su mecenas, y probablemente ambos, tanto el padre como el hijo, lo fueran de Bonafed: Carta 5, texto 16: אם תראה, f. 9: «Si quisieras coger al último de los esclavos para servir a tu majestad, ¡Aquí me tienes!».

${ }^{18}$ Carta 18, שר ואור תעלומות חכמה, f. 45v-47r. 
los poetas de la época y contra los judíos que se encontró al exiliarse en los reinos cristianos. A pesar de no ser un estilo bien visto por los poetas andalusíes, es cierto que todos ellos compusieron al menos un poema quejándose por una afrenta, o contra algún grupo de personas con las que estaba en desacuerdo o con quienes no se sentían identificados. Seguidamente observaremos algunos de estos poemas y sus similitudes o diferencias con el estilo de los escritos de Bonafed.

\section{Šemuel ha-Naguid}

Entre los poemas satíricos que se le atribuyen a Šemuel ha-Naguid, destacaremos aquí el que dedica a unos estudiosos del Talmud ${ }^{20}$, de los que se burla:

Recuerda, hermano, cuando fuimos a la sinagoga aquella tarde / y escuchamos el rebuzno de un burro y los mugidos del ganado berreando en su interior ${ }^{21}$.

Bonafed utiliza el mismo animal, pero con un estilo más hiriente, para burlarse de los ignorantes habitantes de una aldea o de los miembros de la aljama de Zaragoza:

No hay nadie más asno que ellos, todos arden en el fuego de la ignorancia y se ciñen las ascuas de la simpleza. La estupidez de los insensatos es necedad ${ }^{22}$.

En otra carta encontramos el siguiente texto:

No hay nadie más burro que ellos, ya que toda la congregación está formada por ignorantes con un desconocimiento absoluto. Es una congregación de menos de diez miembros por su calidad. En ella hay decenas de millares de hombres que no saben distinguir entre su derecha y su izquierda, y muchas bestias. ${ }^{23}$

\footnotetext{
19 Carta 35, מה החלום הזה, f. 76v-77r.

20 Schirmann, Ha-širá ha- ivrit, vol. 1, pág. 147.

21 Schirmann, Ha-širá ha- 'ivrit, vol. 1, pág. 148, poema 46 (הירהב הזמן).

22 Carta 43, המים טובים, f. 105v-106r.

23 Schirmann 1.
} 
Šemuel ha-Naguid hace gala de un estilo mucho más sutil e insinuante que la batería de improperios que Bonafed suele desplegar en sus escritos. Quizá la frase más ofensiva que aparece en el poema de Šemuel haNaguid sea aquella en la que insinúa que el alma del rabino que dirige la oración es femenina y no masculina y, por tanto, menos capaz:

(...) le contesté así: / « ¿Acaso consideras que tu alma es masculina? / ¡El mismo Dios atestiguaría que eres hembra y no varón!» ${ }^{24}$.

Si comparamos esta manera de expresarse con algunas críticas que aparecen en la obra de Bonafed, podemos apreciar que, en comparación con Šemuel ha-Naguid, el tono crítico y mordaz es mucho más fuerte en aquel poeta. Por ejemplo, en las repetidas acusaciones de sodomía que aparecen en la obra de Bonafed, como en una carta contra los habitantes de una aldea en la que encontramos este pasaje:

Se dan en ella estas tres plagas: las ganancias son la cinta de medir, la salud es la plomada y sus hombres son pocos y malvados, hermanos y compañeros de quienes se acercaron a romper la puerta $(\mathrm{Ge} 19,9)^{25}$.

Podemos apreciar críticas similares en los numerosos reproches a la supuesta homosexualidad de R. Yešu á que aparecen en la carta que envía Bonafed a Ya'acob Albalag ${ }^{26}$ advirtiéndole de este hecho ${ }^{27}$.

\section{Šelomó ibn Gabirol}

Šelomó ibn Gabirol compuso varios poemas criticando a coetáneos suyos, como el que escribió a su salida de Zaragoza ${ }^{28}$ tras una disputa

${ }^{24}$ Schirmann, Ha-širá ha- 'ivrit, vol. 1, pág. 148, poema 46 (הירהב הזמן).

${ }^{25}$ Carta 43, המים הטובים, f. 105v-106r. Los habitantes de Sodoma.

26 Schirman 6.

27 Véase el apartado dedicado a la tradición romance.

28 Debemos recordar que uno de los poemas que escribe Bonafed en contra de la aljama de Zaragoza, el poema Schirmann 4, lo compone inspirándose precisamente en este poema de Šelomó ibn Gabirol, y así lo dice en el encabezamiento el propio Bonafed: «Me puso Dios delante una rima más preciosa que el oro que había compuesto el sabio R. Šelomó ibn Gabirol contra esta malvada comunidad (Zaragoza), pues le habían perseguido sin descanso en aquel tiempo lejano; y comienza así: נחר בקראי גרוני, entonces yo desperté y me dije: 'Yo también haré lo mismo'»: Schirmann, «Ha-pulmus», pág. 34. 
que mantuvo con los mandatarios de la comunidad, en unas circunstancias similares a las que se dieron, casi tres siglos más tarde, con Bonafed y su famosa disputa con los dirigentes de la misma ciudad ${ }^{29}$. El poema al que hacemos referencia es נחר בקראי גרוני, y se trata de una amarga queja que comienza con un lamento por su situación y su soledad para, seguidamente, lanzar una crítica a aquellos que quedan en esa ciudad. En el verso 20 critica su ignorancia y su perversidad:

Entre todos esos perversos e ignorantes, su corazón [el de Gabirol] es el corazón de un sabio ${ }^{31}$.

Luego critica su desvergüenza ante sus faltas y su altanería:

Sus rostros no se sonrojarían ni aunque los tiñeran de púrpura. / Ellos se consideran gigantes, pero yo les veo como langostas ${ }^{32}$.

Bonafed dice así en la primera carta contra la aljama de Zaragoza:

Están desnudos, pero no se avergüenzan, son vasijas vacías ${ }^{33}$.

En la carta contra el joven poeta de Híjar, Bonafed arremete así contra la altanería del muchacho:

Te equiparas al Santo de Israel e incluso de sus ángeles te quejas (...) ${ }^{34}$

Los lamentos de Gabirol continúan, llamando la atención sobre la falta de gusto de los zaragozanos por la poesía que él compone y su ignorancia de la lengua hebrea. Bonafed, en otra carta del mismo ciclo contra los dirigentes de esta ciudad, también se queja de que no entiendan sus poemas:

¿Quién podrá apreciar la belleza de mis palabras? (...) Quizá la mala percepción de esa masa y su ineptitud en los asuntos de la poesía les han obligado a entregar a la menor antes que a la primogénita ${ }^{35}$.

\footnotetext{
29 Véase nota 4.

30 Schirmann, Ha-širá ha- 'ivrit, vol. 1, pág. 207, poema 74, נחר בקראי גרוני.

${ }^{31}$ SchIRMANN, Ha-širá ha- 'ivrit, vol. 1, pág. 207, poema 74, נחר בקראי גרוני, 1. 20.

32 Schirmann, Ha-širá ha- ivrit..., vol. 1, pág. 207, poema 74, נחר בקראי גרוני, 1. 24-25.

33 Schirmann 1.

34 Carta 41, ברן יחד כוכבי בוקר, f. 93v-94v.

35 Schirmann 9.
} 
A pesar de los paralelismos en los temas, motivos universales en gran medida, como veremos al analizar las influencias romances, Bonafed se separa del estilo de Gabirol. Aunque el último sea menos sutil de lo que podemos encontrar en los otros autores de la Edad de Oro, sigue siendo mucho menos hiriente que las sátiras de Bonafed y guarda notables diferencias: Gabirol no critica a sus mujeres, ni reprocha su moralidad detalladamente, ni hay acusaciones cargadas con imágenes sexuales o crueles descripciones físicas, etc.

En definitiva podemos decir que, a pesar de que los poetas de la Edad de Oro sean los modelos clásicos para Bonafed ${ }^{36}$, éste se distancia de su estilo y de la concepción que ellos tenían de la sátira y la burla literarias. Para Bonafed la composición de cartas en las que la invectiva es su principal componente no es algo contrario al buen gusto literario. Las descripciones físicas hirientes, las acusaciones de homosexualidad y la intensidad y mordacidad del tono en el que se componen estas burlas son contradictorias con el espíritu literario de la Edad de Oro andalusí, aunque no con el gusto de la literatura romance, como veremos más adelante.

\section{La maqama}

Además de los ejemplos de los poetas que hemos visto, dentro de la tradición satírica hebrea medieval podemos encontrar ejemplos de sátira social en composiciones en prosa rimada de ficción ${ }^{37}$. De hecho, el estilo que adoptan en sus sátiras o burlas estas composiciones es utilizado conscientemente por Bonafed en una de las cartas que componen el ciclo contra los dirigentes de la comunidad de Zaragoza ${ }^{38}$.

Tomemos como ejemplo el texto del Sefer $\breve{S} a^{\prime} a{ }^{s} u^{\prime} i m$ de Yosef Ibn Zabarra ${ }^{39}$, en el que se describe al amigo de 'Enán Ha-nataš. Aquí, el

\footnotetext{
36 Particularmente Šelomó ibn Gabirol y Yehudá ha-Leví.

37 Sobre la distinción de la «prosa fantástica o de ficción» dentro de la narrativa hebrea, véase A. AlBA, «Narrativa hebrea y sociedad», en La Sociedad Medieval a través de la literatura Hispanojudía, eds. R. IzQuierdo y A. SÁENZ-BADILlos (Cuenca 1998), págs. 239-240.

38 Schirmann 1. Véase el estudio que hace GUTWIRTH a este respecto en: «Leer a Bonafed», págs. 341-357.

39 Schirmann, Ha-širá ha- 'ivrit, vol. 2, pág 51.
} 
propio Enan nos describe al que dice ser su amigo del alma, y que finalmente resulta ser el padre de la muchacha con la que se quiere desposar. Enumera las virtudes de su amigo de forma irónica: todas las virtudes que enumera son en realidad tremendos defectos y faltas gravísimas:

Estas son sus buenas cualidades y sus excelsas virtudes: Odia a todos los sabios y ama a los ignorantes, no tiene límite ni en el beber ni en el comer y nunca reza hasta después de almorzar ${ }^{40}$.

En Bonafed también encontramos textos como la parodia de las tacanot que compuso la impía aljama de Zaragoza, en el que se ridiculiza la perversidad y la ignorancia de estas gentes de forma irónica:

Acordaron [en las leyes comunales] también que a todo hombre de corazón puro, pobre y que no tiene de qué avergonzarse, se le arroje a los perros ${ }^{41}$.

Y acusaciones de glotonería, como las dirigidas a Abraham Muriel en otra carta del mismo ciclo:

Cuando está desganado es capaz de comerse un tartemar $^{42}$ de carne y un $\log ^{43}$ de vino con ira y enfado ${ }^{44}$.

Yosef ibn Zabarra enumera también las ciencias que conoce este impío personaje amigo de Enan, y queda patente su ignorancia en casi todos los campos de la ciencia: la física, la medicina, la astronomía, la Torah e incluso la lógica:

- Y de la ciencia de las estrellas, ¿qué sabe?

- Sabe que cuando luce el sol es de día y cuando salen las estrellas reconoce que ha llegado la noche ${ }^{45}$.

En la primera carta de la polémica contra la aljama de Zaragoza (Schirmann 1), Bonafed describe también la ignorancia de Yosef ben

\footnotetext{
${ }^{40}$ Schirmann, Ha-širá ha- 'ivrit, vol. 2, pág 52, 1. 21-23.

${ }^{41}$ Schirmann 3.

${ }^{42}$ Medida de peso.

${ }^{43}$ Medida de capacidad para líquidos.

${ }^{44}$ Schirmann 2.

${ }^{45}$ Schirmann, Ha-širá ha- 'ivrit..., vol. 2, pág 53. 1. 52-53.
} 
Yešu'á, el impío rabino siciliano, enumerando su desconocimiento de las distintas ciencias, como la medicina, la astronomía, la lógica o la física (la naturaleza):

También vienen a él, para estudiar la ciencia de la astronomía, los espíritus, los fantasmas y los demonios nocturnos, las lechuzas y los búhos. Si pone su mano en el trono del que conoce los caminos del firmamento, la rueda se sale de su eje ${ }^{46}$.

Bonafed utiliza algunas de las imágenes y de los recursos lingüísticos que aparecen en el capítulo antes citado del Sefer Ša'ašu'im. Particularmente destacable en este aspecto es la primera carta que inicia el ciclo de escritos en contra de la aljama de Zaragoza ${ }^{47}$. Sin embargo, Bonafed adopta nuevos contenidos y tonos que habrían sido inconcebibles en la literatura hebrea clásica, como las continuas referencias a los actos de sodomía del rabino Yosef ben Yešu'á, o la profusión de descripciones físicas hirientes y soeces ${ }^{48}$.

Existen otras figuras, que Bonafed utiliza también en sus invectivas en contra de los dirigentes de la aljama, que parece que guardan relación, al menos formalmente, con algunas de las empleadas por Yosef ibn Zabarra; tal es el tratamiento de la figura social del hazán o cantor ${ }^{49}$, a quienes Zabarra no les tiene ninguna estima y los describe como jactanciosos e ignorantes, además de ladrones:

Cuando el hazán está en su puesto permanece colocado por encima del resto de la gente que lo acompaña, y al verse tan alto y elevado,

46 Schirmann 1.

47 Schirmann 1. Sobre las similitudes entre esta carta y el género de la maqama, véase Gutwirth, «Leer a Bonafed», págs. 341-357. Merece la pena destacar el hecho de que la carta de Bonafed intercala versos en la prosa, igual que se suele hacer en la maqama. En general podemos decir que el estilo de la carta de Schirmann 1 se parece mucho al de esta forma narrativa clásica.

48 Estos recursos serán muy utilizados por composiciones populares romances de la época, como las Coplas de la Panadera. Sobre las similitudes entre las Coplas de la Panadera en su versión catalana y los escritos de Bonafed en contra de los dirigentes de la comunidad de Zaragoza, véase: GutwirTh, «Contempt...», págs. 83-98.

49 Sobre los distintos tipos sociales en la narrativa hebrea de la España cristiana, véase A. NAvarro PeIro, «Tipos sociales en la narrativa hebrea de la España cristiana», en La Sociedad Medieval a través de la Literatura Hispano-Judía, eds. R. IzQuIERdo y A. SÁEnZ-BAdiLlos (Cuenca 1998), págs. 256-277. 
piensa que esto se debe a su honor y dignidad y entonces cae en su tontería. Además, el aire que sale de su garganta desgarra el aire y eso produce la voz, cuya naturaleza es caliente y seca. La voz sube siempre a su cerebro y lo seca, y con la sequedad del cerebro se produce la tontería y la necedad de cualquiera ${ }^{50}$.

Bonafed utilizará esta carga negativa que se aplica al cargo de hazán en la tradición literaria hebrea andalusí para usar esta palabra como un insulto. Así, en la descripción que hace de Abraham Šu'aib:

El sexto es Abraham Šu'aib (...) Es un hazán que sustenta a todo el mundo con sus prostituciones y le parece agradable la cabra del sacrificio por el pecado ${ }^{51}$.

Podemos concluir hasta aquí que Bonafed hereda de la tradición hebrea los recursos formales con los que compondrá sus escritos, particularmente de las imágenes que aparecen en las maqamas, pero difiere en el tono y en algunos motivos (sodomía y burlas sobre el físico) de la tradición clásica.

\section{LA SÁTIRA EN LAS TRADICIONES LITERARIAS ROMANCES}

Existen numerosos estudios sobre la sátira y la invectiva en la literatura romance durante la Edad Media ${ }^{52}$. Este estilo tiene una larga tradición en las tres grandes ramas romances que confluyen en la literatura peninsular: la literatura galaico-portuguesa, la literatura castellana y la provenzal. Contamos con estudios anteriores que se ocupan en la influencia de estas literaturas en la poesía hebrea, particularmente en la invectiva, en épocas anteriores ${ }^{53}$ pero nos fijaremos ahora en la obra literaria romance que se

${ }^{50}$ Navarro Peiro, «Tipos sociales», págs. 268-269.

${ }^{51}$ Schirmann 2.

52 R. MenÉndez Pidal, Poesía juglaresca y orígenes de las literaturas románicas (Madrid 1957; $2^{\mathrm{a}}$ ed. Madrid 1962); J. PAREDES, Las cantigas de escarnio y maldecir de Alfonso X (Londres 2000). M. DE RiqueR e I. DE RiQueR, La poesía de los trovadores (Madrid 2002); J. Rodríguez Puértolas, Poesía de protesta en la Edad Media castellana (Madrid 1968); Scholberg, Sátira e invectiva, etc.

${ }^{53}$ Nos referimos principalmente al estudio citado anteriormente de SÁEnz-BADILLos («Hebrew invective Poetry») sobre la invectiva en la poesía de Todros Abulafia. 
produce durante el s. XV. Un tipo de poesía social que pudo haber influido en la literatura de sátira social y de invectiva que compuso Bonafed, tal y como adelantó Gutwirth ${ }^{54}$, son las Coplas de la Panadera.

Se trata de una obra anónima que gozó de gran difusión. Utiliza como hilo argumental los hechos de la Batalla de Olmedo (1446) entre Juan II y Don Álvaro de Luna para ridiculizar a los caballeros que participaron en ella. En un ambiente de cambio, en el que escriben insignes figuras como el Marqués de Santillana y otros poetas cortesanos, también se cultiva este tipo de literatura popular de las coplas. Es una época en la que se pierden las virtudes tradicionalmente adscritas a la nobleza y se comienza a percibir claramente el ascenso de una nueva «nobleza», la burguesía, criticada ampliamente en la obra de Bonafed.

En las Coplas de la Panadera se alude a los caballeros que participan en la batalla con nombres propios ${ }^{55}$, al igual que hace Bonafed en la carta que dedica a detallar los crímenes y las faltas de los dirigentes de la comunidad de Zaragoza ${ }^{56}$. En esta carta se describe a estos mandatarios uno a uno y por su nombre, en un tono muy similar al de las coplas, deteniéndose en referencias hirientes a su físico, como las que aparecen en las Coplas de la Panadera, por ejemplo, cuando habla de la negrura de López de Saldaña:

Fernán López de Saldaña / más negro que una caldera ${ }^{57}$.

Bonafed, en otra carta, describe así a Mošé ben Yamín:

El tercero se parece a un cuervo y es negro, Mošé ben Yamín. No cree en sus santos; es como alquitrán ardiente, materia bruta sin forma ${ }^{58}$.

54 Gutwirth, «Leer a Bonafed».

55 Son numerosas las composiciones de esta época en las que se introducen nombres propios de personajes conocidos para criticarlos o burlarse de ellos. Además de las Coplas de la Panadera, tenemos una composición de un poeta del Cancionero de Baena, llamado Ferrán Manuel de Lando (primera mitad del s. XV), que compone un poema parecido al de las Coplas de la Panadera. En esta obra se escoge como telón de fondo el relato de un torneo en Valladolid en el que todos los caballeros se comportan como cobardes. Son mencionados por su nombre y se atacan sus defectos físicos y moralidad: gordos («relleno como tonel»), a propósito de Pero Manuel, o afeminados («femenino, liberal»), a propósito de Rodrigo de Perea (Rodríguez PuÉrtolas, Poesía crítica, pág. 80).

56 Schirmann 2

57 Rodríguez Puértolas, Poesía de protesta, pág 200.

58 Schirmann 2. 
En las coplas se burlan también de la obesidad del conde de Ribadeo:

Con palabra lisonjera / y con talle gordo y feo, / el conde de Ribadeo / sin armas apareciera ${ }^{59}$.

Bonafed dice de Bonaštruc de Salinas:

Era como unos huesos secos pero, acumulando fe en cualquier cosa, se ha hecho gordo y obeso ${ }^{60}$.

Y de Abraham Muriel:

$\mathrm{Su}$ rostro se parece al de los porqueros y da sentido a la palabra «defecto». Es gordo como Eglón, espinoso como el cardo ${ }^{61}$.

Y también de R. Yešu'á de Sicilia:

Su altura es la de un dedo meñique, lo mismo que su anchura ${ }^{62}$.

Y sobre el mismo personaje se dice en otra carta:

¡Fíjate en su aspecto, una porción de hombre! ¡Mira dónde llega su estatura, pequeña como la de una babosa, sin un solo hueco, sin cuerpo ni proporciones! ${ }^{63}$

Como podemos comprobar, recrearse en los defectos físicos se convierte en una constante en las sátiras de Bonafed, algo que no ocurría en la tradición hebrea anterior.

Las acusaciones de glotonería o de exceso en el beber aparecen también en las coplas y en Bonafed, coincidiendo en el tono. En las coplas se dice:

(...) el mayor caballerizo (...) fue el primero que fuyera / pero un lindo encuentro diera / en un gran odre de vino / fizole perder el tino ${ }^{64}$.

Y Bonafed describe a Abraham Muriel como:

\footnotetext{
59 Rodríguez Puértolas, Poesía de protesta, pág. 204.

${ }^{60}$ Schirmann 2.

${ }^{61}$ Schirmann 2.

${ }^{62}$ Schirmann 1.

${ }^{63}$ Schirmann 6.

${ }^{64}$ Rodríguez Puértolas, Poesía de protesta, pág. 206.
} 
(...) capaz de comerse un tartemar de carne y un log de vino. ${ }^{65}$

También describe a Yosef ben Yešu'á como un borracho despreciable:

(...) y a veces coge dinero de la limosna y del Tamhuy ${ }^{66}$ para llenar su vientre de vino. Desde lejos se huelen los aromas de la jarra, pero no se avergüenza en absoluto (... ${ }^{67}$

También son numerosas las acusaciones de sodomía en la literatura romance y en la obra de Bonafed. Tomemos, por ejemplo, un verso del poema de Alfonso Álvarez de Villasandino (s. XV) contra el cardenal Pedro Frías, favorito del rey Enrique III:

Por Júpiter sean fuegos esparçidos / en los senadores que son de Sodoma (...) ${ }^{68}$

En Bonafed, aparecen continuas referencias a la homosexualidad de R. Yešu'á en diversas cartas de la polémica contra la aljama de Zaragoza. En una de ellas, le reprocha a su amigo Ya'acob Albalag que haya acudido a este rabino para estudiar lógica y le advierte de su ignorancia, de su maldad y, como no, de sus tendencias sexuales:

Y aún me causa más dolor el hecho de que esa cosa hedionda, inaceptable [refiriéndose a R. Yešu'á], le gusten los muslos de los varones. Siendo tú un hombre agradable, con bellos ojos, ¿quién sabe si os acostáis juntos, o si su mala inclinación arde por Jacob cual fuego ardiente? (...) También el inaceptable [R. Yešu'á] tiene buen aspecto, ese guiso rojo que planta sus tiendas hasta Sodoma. Quizá te enseñe «Ma'asé Mercabá» para hacer sus actos extraños, pues fuerte como la muerte es el amor. La casa de Jacob es fuego y llamas la de Yosef ${ }^{69}$.

${ }^{65}$ Schirmann 2. Pasaje citado anteriormente en el apartado sobre la maqama (notas 42, 43 y 44).

${ }^{66}$ Caja comunal de limosna pública de la que se reparte diariamente el alimento para los necesitados.

${ }^{67}$ Schirmann 1.

68 En J. J. Calvo Pérez, La poesía de Alfonso Álvarez de Villasandino (Burgos 1998), pág. 213.

${ }^{69}$ Schirmann 6. 
Existen también tipos sociales que son blanco de las burlas a lo largo de los siglos XIV y XV, como es el caso de la figura del eclesiástico o el cura de aldea, como podemos ver en el Rimado de Palacio de López de Ayala (1332-1407), donde los denuncia reprochándoles que son mundanos y que solo desean hacerse ricos:

non saben las palabras de la consagración, / nin curan de saber, nin lo han a coraçon; / Si pueden aver tres perros, un galgo y un furon ${ }^{70}$.

O en la Dança general de la muerte, donde se pone en boca del canónigo respondiendo a la muerte:

Vete agora, muerte, non quiero ir contigo (...) en folgura vivo, non en turbación, / aún este otro día hube provisión / desta calongía que me dio el prelado: / desto que tengo só bien pagado, / vaya quien quisiere a la tu vocaçión ${ }^{71}$.

Bonafed probablemente usa estas mismas críticas asociadas al tipo social del cura o eclesiástico transfiriéndolas al tipo andalusí del hazán ${ }^{72}$, como hemos visto en el apartado dedicado a la maqama. Para Bonafed el vocablo de hazán ya tiene una connotación intrínseca de insulto que probablemente provenga del estereotipo andalusí reforzado con el del cura romance:

El sexto es Abraham Šu'aib (...) Es un hazán que sustenta a todo el mundo con sus prostituciones y le parece agradable la cabra del sacrificio por el pecado ${ }^{73}$.

En resumen, se puede concluir que el tono de la sátira y de la invectiva en las diversas literaturas romances siempre fue mordaz e hiriente, y especialmente en la producción literaria del s. XV, donde hallamos numerosos ejemplos. Este característico tono mordaz e hiriente, que se detiene en las descripciones sobre el físico y se burla de la homosexualidad de sus víctimas, se encuentra más cercano al estilo de la invectiva que cultiva Bonafed que al de sus antecedentes clásicos, los poetas hispano-hebreos de la Edad de Oro.

${ }^{70}$ Scholberg, Sátira e invectiva, págs. 181-182. Cf. Rimado de Palacio, estr. 223225 .

${ }^{71}$ Rodríguez Puértolas, Poesía crítica, pág. 57. Cf. estr. 345-350.

${ }^{72}$ Véase Navarro Peiro, «Tipos sociales», págs. 268-269.

${ }^{73}$ Schirmann 2. 


\section{CONCLUSIÓN}

Podemos afirmar que la sátira que cultiva Bonafed es, por una parte, heredera de una tradición literaria y cultural muy antigua, la tradición hebrea andalusí, con la que el propio autor se identifica, sintiéndose incluso continuador de la misma ${ }^{74}$, y por otra, de la tradición romance.

Al hablar de la tradición hebrea hay que señalar que, en la época de Bonafed, había sufrido algunas transformaciones. En la Edad de Oro de la literatura hispano-hebrea, la concepción que se tiene de la invectiva y la sátira no coincide con la de Bonafed. Para éste, las invectivas dirigidas a personajes con nombres y apellidos, el uso de imágenes soeces y groseras, o las descripciones físicas hirientes, y en muchos casos las acusaciones de sodomía y los insultos, son parte de un género que es digno de ser puesto por escrito y cultivado. Estos motivos, sin embargo, ni se dan en la poesía andalusí, ni están bien considerados ${ }^{75}$.

Por otra parte, ya hemos visto que en las diversas literaturas romances a lo largo de los ss. XIV y XV, hay testimonios textuales de la sátira y la invectiva, y hemos podido ver cómo éstos guardan cierta similitud, si no literal, sí de tono o de estilo con la sátira que cultiva Bonafed. En estas literaturas es muy frecuente descender a niveles de lenguaje soeces e hirientes, aludiendo a los personajes criticados con su nombre y haciendo descripciones crueles, mofándose incluso de la homosexualidad de los personajes vilipendiados.

Se trata sin duda de dos concepciones literarias radicalmente diferentes, la tradición romance y la tradición hebrea andalusí, pero es también indudable que en el $\mathrm{s}$. XV se ha producido ya un gran cambio con respecto a la Edad de Oro andalusí ${ }^{76}$. El tejido social en el que se creó esta literatura no es el mismo, e incluso ha cambiado la cultura mayoritaria en la

74 Bonafed dice así en uno de sus poemas: «Subieron primero ellos (los antiguos poetas) a los huertos de la poesía / Y recogieron sus flores y lirios. / Casi no dejaron a los que siguieron / Más que sus pieles y pepitas. / (...) / Vendimiaron ellos las viñas placenteras, mas / Nosotros rebuscamos el rebusco de sus cepas» (Poema 155) (עד אן מאור, f. 84v-85v).

75 Sobre las costumbres y vicios satirizados en la poesía romance del s. XV, que coinciden, en muchos casos, con los que aparecen en la sátira e invectiva de Bonafed, véase Scholberg, Sátira e invectiva, págs. 281-302.

76 Sobre este tema véase ScheindLin, «Secular Hebrew Poetry in Fifteenth C. Spain», en B. Gampel (ed.), Crisis and Creativity in the Sephardic World. 1391-1648 (New York 1997), págs 25-37; ID., «The Hebrew Qasida in Spain», en Qasida Poetry in Islamic Asia and Africa. VI (New York 1996), págs. 128-135. 
que se fraguaron los textos de los poetas de la Edad de Oro. La lengua de la norma culta, en la que se enmarcan las bellas letras hebreas, ya no es el árabe, sino el romance (con las peculiaridades de las respectivas regiones y reinos). Se puede, en definitiva, afirmar que hemos entrado en un periodo completamente diferente que produce una literatura con características propias. Esta literatura no es un mero epígono de una tradición literaria anterior. La sátira y la invectiva son quizá uno de los estilos en los que esta evolución se nota más, ya que reflejan de una forma más directa los cambios sociales vividos en esta nueva etapa, así como los conflictos en los que el judaísmo español está sumido.

Este periodo de la literatura hebrea ha sido tratado tradicionalmente como el agónico final de una tradición literaria que desaparece y a la que se intenta emular sin éxito. Hoy en día la investigación de este periodo se centra en estudiar sus peculiaridades e innovaciones y el mundo de imágenes propias que encierra ${ }^{77}$, y está logrando separar la literatura producida en esta época de un simple juicio estético, centrándose en analizar sus formas y su contenido para disfrutar así de un mundo que guarda sus propias singularidades con respecto a la literatura hebrea de la Edad de Oro y a la literatura romance que la rodea, a pesar de utilizar ambas fuentes.

En definitiva, podemos decir que Bonafed cultivó una literatura que hereda el idioma y la forma de escribir de los poetas hispano-hebreos, pero dándole un nuevo tono a sus composiciones inspirado en las formas literarias romances de su época ${ }^{78}$.

${ }^{77}$ Véanse, entre otros, los trabajos de R. Scheindlin, A. Sáenz-Badillos, J. Targarona, E. Gutwirth y E. Seroussi, citados en este artículo.

${ }^{78}$ Sobre el tema de las formas romances en la literatura hebrea del s. XV, véase E. Seroussi, «Catorce canciones en romance como modelos de poemas hebreos del s. XV», Sefarad 65 (2005), págs. 385-411. 


\section{RESUMEN}

El presente artículo trata de ahondar en el estudio de la obra recogida en el diwan de R. Šelomó bar Re'ubén Bonafed mediante un análisis literario de la sátira y la invectiva que se encuentran en sus textos en prosa. Se pretende, de este modo, comprender mejor la obra de Bonafed y sus influencias, sobre todo las externas a la tradición hebrea, a través de un estudio comparativo entre la sátira y la invectiva cultivadas en la época clásica de la literatura hispanohebrea y la que se producía en lengua romance en los ss. XIV y XV.

Palabras Clave: Bonafed, sátira, invectiva, literatura hebrea, siglo XV.

\section{SUMMARY}

The aim of this work is to achieve a better understanding of R. Šelomoh bar Re'uben Bonafed's diwan and the influences it received especially from literary works of a nonHebrew origin. This is made through a comparative study between the satirical and invective texts written in the classical period of the Hebrew-Spanish literature and those written in Romance language in the $14^{\text {th }}$ and $15^{\text {th }}$ centuries.

KeYwords: Bonafed, Satire, Invective, Hebrew Literature, Fifteenth Century. 